\title{
Quaternary earthquakes: geology and palaeoseismology for seismic hazard assessment
}

\author{
Blumetti, A. M. (1), Grützner, C. (2), Guerrieri, L. (1), Livio, F. (3) \\ (1) ISPRA, Geological Survey of Italy, Via Brancati, 48, 00144 Rome, Italy \\ (2) COMET, Bullard Labs, Madingley Rise, Madingley Road, Department of Earth Sciences, University of \\ Cambridge, CB3 OEZ, Cambridge, UK \\ (3) University of Insubria, Via Valleggio 11, 22100, Como, Italy
}

\section{Why does Quaternary geology contribute to seismic hazard assessment?}

Strong earthquakes are an essential source of information for research on active tectonics and seismic hazard. For example, large seismic events allow identifying active faults and determining fault kinematics. Teleseismic waveform analyses are used to determine dip and strike of the fault plane and the focal depth (e.g., Hartzell and Heaton, 1983; Jackson and McKenzie, 1984; Maggi et al., 2000). Geodetic techniques like GPS, radar interferometry (InSAR) and pixel matching allow to reveal the surface deformation pattern due to large events and can be used to model the geometry of the causative faults and the amount of slip (e.g., Wald et al., 1996; Talebian et al., 2006; d'Oreye et al., 2011; Elliott et al., 2013, 2016; Fielding et al., 2013; Zhou et al., 2016). Earthquake surface ruptures typically preserved for magnitudes larger than 6.0 tell us much about fault geometry and parameters including slip vector, slip distribution, possible fault interaction, and the landscape response to large tectonic events (e.g., Koto, 1893; Philip and Meghraoui, 1983; Xu et al., 2009; Oskin et al., 2012; Gold et al., 2013). Surface rupture data are thus valuable for piecing together the picture of regional tectonics. In seismic hazard studies, modern large earthquakes do not only reveal capable faults (Azzaro et al., 1998), but also shed light on the ground motion that affects the epicentral area. Studies of large earthquakes are used to estimate the attenuation relationships between earthquake magnitude and the intensity distribution (e.g., Dahle et al., 1990; Sadigh et al., 1997; Bindi et al., 2006). Furthermore, coseismic effects contribute to the overall hazard and can be studied in modern events (Michetti et al., 2007; Porfido et al., 2015).

All these studies have in common that the observation period only covers not more than one hundred years, i.e. the onset of instrumental earthquake detection and modern studies of earthquake geology. However, earthquake recurrence intervals exceed this time span even in the fastest deforming areas of the world. Hence, it is not possible to analyse the entire earthquake cycle with these methods. Often it remains unclear whether or not modern earthquakes represent the worst case scenario, and most active faults in the world did not rupture in the instrumental period at all. Thus, it is essential to gather earthquake data in a longer time scale.

Studies of historical seismicity in written records (Ambraseys, 1971, 1983) and archaeoseismology (Stiros and Jones, 1996; Noller, 2001; Galadini et al., 2006; Rodríguez-Pascua et al., 2011) can extend the earthquake record to several millennia in areas like China, the Mediterranean or the Middle East. However, information in historical sources on active faults and earthquake effects on the environment are frequently incomplete and not homogeneous. 
For this reason, collecting meaningful data on fault activity and long-term seismic hazard often requires the integration of information about (palaeo-) earthquake environmental effects (i.e., EEEs; Michetti et al., 2005; Papanikolaou et al., 2015) and results of palaeoseismological studies (e.g., Galli et al., 2008; Reicherter et al., 2009; Grützner et al., 2013). The effects of large earthquakes can be preserved in the geological record for thousands of years and even longer: repeated events of surface faulting and folding create tectonic landforms such as fault scarps, fault-generated mountain fronts, drainage patterns indicative of vertical tectonic motion, etc. (e.g., Wallace, 1978; Blumetti et al, 1993; Bull, 2007; Blumetti and Guerrieri, 2007; McCalpin, 2009). The distribution, variety, and amplitude of such landforms have been used to evaluate the seismic potential of a region employing the concept of the so-called "seismic landscape" (e.g., Serva et al., 2002; Dramis and Blumetti, 2005; Michetti et al., 2005; Michetti et al., 2012). This concept includes the tectonic geomorphology of a region as well as the geological record of past seismic activity. Quaternary science techniques are increasingly employed to investigate the geological record, and interdisciplinary studies have proven necessary and successful to reveal a fault's or region's seismic history. A large variety of tools is available nowadays to the earthquake geologists. Classical on-fault investigations, such as palaeoseismological trenching, coupled with tectonic geomorphology, still form the backbone of palaeo-earthquake research (e.g., Vittori et al., 1991; Dramis and Blumetti, 2005; Bull, 2007; McCalpin, 2009, and many others). The latter takes benefit from recent developments in producing high-resolution digital elevation models (DEM) from data sources such as airborne laser scanning/LiDAR (Haugerud et al., 2003; Arrowsmith and Zielke, 2009), Structure-from-Motion (SfM) photogrammetry (Bemis et al., 2014; Reitman et al., 2015; Elliott et al., 2016), and stereo and tristereo satellite imagery (Zielke et al., 2015). Progress in dating techniques such as exposure dating using cosmogenic nuclides, Uranium-Thorium series dating, and luminescence techniques also improved the resolution and reliability of this kind of studies (Benedetti and Van Der Woerd, 2014; Gregory et al., 2014; Rhodes, 2011, 2015; Middleton et al., 2016). Increasing attention is being paid in the last decade to the analysis of EEEs as earthquake proxies and the application of the ESI scale, an intensity scale based only on EEEs developed in the frame of INQUA (Michetti et al., 2007; Serva et al., 2007, 2016; Papanikolaou, 2011; Moreiras and Páez, 2015; Quigley et al., 2016). These studies use earthquake proxies like mass movements, liquefaction, tectonic uplift or subsidence, tsunami, and hydrological anomalies to analyse past seismic events. Related approaches utilise the effects of earthquakes on archaeological sites (Rodríguez-Pascua et al., 2011) and the coastal impact of tsunamis (Lario et al., 2016).

The interaction of different depositional and erosional processes, climate variations, and anthropogenic modifications can lead to a highly complex geological record which complicates the identification of tectonic deformation and secondary earthquake effects in the stratigraphy (Nikonov, 1995). However, the manifold of overlapping and interacting processes also presents a unique opportunity since there are plenty of different ways in which evidence for past seismicity can be recorded. Careful and detailed studies of the Quaternary geological record of earthquakes may include disciplines such as stratigraphy, pedology, limnology, palynology, glaciology, speleology, archaeology, and geoarchaeology, aided by geophysical techniques and Quaternary dating methods.

For example, palaeosols that develop on stable surfaces and which are successively covered by colluvia, as accommodation space has been created by normal faulting, are used as stratigraphic markers in palaeoseismic trenches. However, they are often hard to be identified as younger soil develops on top of them, alterating the older units. This is especially problematic when the sum of coseismic and postseismic offsets is small and only thin layers of colluvium cover the palaeosols. 
Groundwater flow, carbonate precipitation, creep, and other mechanisms may also obscure older soils such that the trench stratigraphy is difficult to interpret. Dating palaeosols in the absence of charcoal or preferred radiocarbon material can also be challenging. These problems can often be overcome by detailed palynology, mineralogy, and sedimentology studies. The stratigraphic context of the palaeosols in the first place is the key to unravel the formation and deformation history. Earthquakes with small surface offsets may still leave their geological traces along the fault as open fissures/cracks or in the form of thin anomalous sediment layers due to ponding or mobilisation of slope deposits and dust. The environmental information recorded by old soils can further help to identify phases of soil formation and the response to climatic events. These data can then be used to distinguish sedimentary units that are indicative of seismic activity. Innovative dating techniques with high accuracy and precision can further help to identify the relevant layers in the stratigraphy. In the scenario discussed, integrated work across a number of Quaternary science disciplines would be the key to extract the earthquake information from the geological archives.

As more and more modern examples of earthquakes and earthquake sequences are now available, it becomes increasingly clear that the geological record can be difficult to unravel for other reasons, too. Surface rupture patterns can be highly complex in single events (e.g., Fletcher et al., 2014; DeLong et al., 2016). In earthquake sequences like the one that struck Central Italy in 2016, repeated ruptures of the same fault might occur (Figure 1). These phenomena are obvious issues in palaeoseismological research. While it may never be possible to solve these problems entirely, new techniques and approaches can help to narrow down uncertainties and to better understand past earthquakes.

For the reasons above, Quaternary geology is an essential tool for seismic hazard assessment especially where the surface expression of active faulting is either rapidly obscured by erosion/sedimentation, or the recurrence intervals of surface rupturing earthquakes are very long. This concerns many areas of the world, like stable continental regions such as Central Asia, where earthquake tend to be large but infrequent (e.g. Prentice et al., 2002; Campbell et al., 2015; Grützner et al., 2017), but also regions such as Central Europe (Štěpančíková et al., 2010; Špaček et al., 2015; Grützner et al., 2016). Long recurrence intervals indeed are one of the greatest challenges in earthquake geology research and tectonics, but also in seismic hazard studies (Liu and Stein, 2016). In these cases geomorphological studies on drainage patterns, fluvial and marine terraces, and morphometric analyses can help to identify active faulting. High-resolution geophysical studies can help to identify faults that do not have a surface expression at all and to image their shallow structure.

In the following section we discuss a case study to illustrate how modern earthquakes help to understand the tectonics of Central Italy, and what a sequence of moderate events means for palaeoseismology and seismic hazard research.

\section{An illustrative case study: the Central Apennine Fault Systems}

The Central Apennines in Italy are a NW-SE trending mountain range that presently undergoes NESW extension in its sectors close to the main water divide. Since the Pliocene, a number of elongated basins bounded by normal faults (i.e., grabens or half-grabens) have formed by repeated cycles of earthquakes (Cinque et al., 1991; Cello et al., 1997). The entire region is thus subject to a moderateto-high seismic hazard (Galadini and Galli, 2000; Meletti et al., 2016) and in the past 100 years some 
of the strongest earthquakes ever recorded in Italy occurred in this region. The analysis of these events from a geological perspective has shaped the understanding of active faulting and seismic hazard in Italy and beyond.

\section{Fucino 1915}

On 13 January, 1915, a shallow earthquake with a magnitude of M7 occurred in Fucino Basin. This event caused widespread devastation and left $~ 30,000$ people dead. It took decades for the region to recover and even today the traces of the earthquake are still visible in the epicentral area. The surface rupture pattern was described by Oddone (1915). Blumetti et al. (1988) reconstructed the 1915 surface faulting trace by comparing Oddone's report with the impressive tectonic landforms that characterize the Fucino Basin. They also collected original data of coseismic earthquake ground effects through interviews made in 1985 with old locals who had experienced the 1915 event. As a result, among other indicators, they have recognised the occurrence of continuous 1915 surface faulting at the base of a Middle Pleistocene tectonic terrace, testifying that this landform is the result of repeated 1915-like surface faulting events. This large event traced, for Italian geologists, the conceptual model of the seismic landscape of the Central Apennines and laid the groundwork for further studies on earthquake geology in the area. Some years later, palaeoseismological investigations revealed the previous earthquake history of the causative faults and brought to light evidence for historical and pre-historical surface faulting occurrence (Michetti et al., 1996; Galadini and Galli, 1999). Moreover, geodetic studies were used later to investigate the source mechanism of this large event (Ward and Valensise, 1989).

\section{Umbria and Marche}

On September-October 1997 a seismic sequence hit the Umbria-Marche region. The epicentres were located in the Colfiorito area. Two main shocks occurred on September 26 ( $M_{w 5} 5$ and $M_{w 6.0}$ ) followed by another earthquake on October $14\left(\mathrm{M}_{\mathrm{w}} 5.6\right)$. These events were also studied through InSAR modelling (Stramondo et al., 1999): a relatively young innovation in imaging earthquakes back then. At that time the quality of InSAR data was relatively low compared to modern studies. The data did not offer a direct recognition of discrete surface deformation which would allow modelling inversion solutions for fault geometry and slip. Strong motion data and geodetic analysis, however, were used to gather this information. The occurrence and extent of surface faulting in the 1997 earthquakes was debated. Some authors (Cello et al., 1998; Cinti et al., 2000; Vittori et al., 2000) interpreted the surveyed ground ruptures as evidence of coseismic surface faulting ranging between 6 and $12 \mathrm{~km}$ in length and between 2 and $10 \mathrm{~cm}$ in max displacement, which are typical values for moderate earthquakes ( $\mathrm{M}^{\sim} 6$ ). Conversely, other researchers (e.g. Galli et al., 1998; Messina et al., 2002) interpreted the same features as the result of compaction of debris deposits driven by gravitational motion. Furthermore, a large number of secondary effects were observed (e.g. landslides, ground cracks, liquefactions, etc.) in an area in the order of $1000 \mathrm{~km}^{2}$ (Guerrieri et al., 2009). Beyond the open debate on the interpretation of ground ruptures, the distribution of coseismic primary and secondary effects is consistent with the "seismic landscape" of the Colfiorito basin that is the result of several 1997-like earthquakes over a long geological time interval (cf., Serva et al., 2002). In this perspective, the 1997 seismic sequence is considered "characteristic" for the area and, therefore, it is indicative of the level of seismic hazard.

L'Aquila 2009

The 2009 L'Aquila, Italy, earthquake was one of the best-studied earthquakes in Europe in the last decades (e.g., Chiarabba et al., 2009; Walters et al., 2009; Cheloni et al., 2010). This event caused a 
few kilometres of surface faulting ( 3 to $19 \mathrm{~km}$, according to different authors; i.e. Alessio et al., 2009; Boncio et al., 2010; Vittori et al., 2011) mainly along the Paganica fault, which borders the central section of the L'Aquila basin to the NE. Even though the coseismic throw did not exceed $15 \mathrm{~cm}$, the rupture had broken the Gran Sasso aqueduct, which was providing water to L'Aquila city. This fact has strongly increased the awareness of surface faulting hazard in Italy.

Beyond the fierce debate on earthquake forecasting and risk communication triggered by the "L'Aquila Trial" (Cocco et al., 2015; Stucchi et al., 2016), the L'Aquila event led to a strong nationwide effort aimed i) at revising the maps of active/capable faults, including additional palaeoseismological studies; and ii) at undertaking microzonation studies at municipality level in the epicentral area. Thanks to these combined efforts much light has been shed on the tectonic structure of the Central Apennines and its earthquake history (e.g., Tertulliani et al., 2009; Galli et al., 2010, 2011; Cinti et al., 2011; Vittori et al., 2011; Chiaraluce, 2012; Giaccio et al., 2012; Blumetti et al., 2013; Galli et al., 2016; Pucci et al., 2016), although the region was in the research focus already before 2009 (Blumetti, 1995; Pantosti et al., 1996; Blumetti and Guerrieri, 2007; Salvi et al., 2003).

\section{Amatrice and Norcia, 2016}

The latest insights into the earthquake behaviour of the Central Apennines became possible during the seismic sequence that started in August, 2016, and which was still ongoing in February, 2017 (four earthquakes $M_{w}>5$ on 18 February, 2017). Mainshocks between $M_{w} 6.0-6.5$ struck an area between Campotosto in the south (partially overlapping the $\mathrm{N}$ tip of the L'Aquila earthquake sequence) and Norcia in the north. This long-lasting sequence was characterised by successive strong mainshocks, hitting a ca. $80 \mathrm{~km}$ long sector of the chain through the repeated re-activation of the same faults (Figure 1) and, contemporarily, a progressive migration of seismicity on adjacent tectonic structures. Research teams from many different institutions surveyed the area soon after the largest events and a great amount of data was collected and readily published on surface faulting and earthquake-induced environmental effects (EMERGEO Working Group, 2016; Livio et al., 2016; Pucci et al., 2017). Previous palaeoseismological studies (e.g., Galadini and Galli, 2003) have found confirmation in the observations related to these events, providing a valuable experimental validation on previous deductions based on palaeoseismic evidence.

One of the main turning points in these events is the availability and increased quality of data on earthquake-induced ground deformation. Thanks to an increased temporal resolution offered by many observation satellite missions (i.e., ESA Sentinel-1, COSMO SkyMed and PALSAR among others) and thanks to continuous GPS network data (Cheloni et al., 2016), scientists had the opportunity to observe the crustal deformation induced by each one of the main shocks composing this sequence, to recognize areas affected by distributed faulting/deformation, and to monitor post-seismic deformation. Inversion of ground deformation data (Lavecchia et al., 2016) together with seismological strong motion datasets and seismicity relocation (Michele et al., 2016) allowed to model the possible seismogenic sources at depth, allowing to better constrain the observations from the surface and the shallow geological record. An intense debate started in the scientific community regarding the role of the seismogenic source in inducing surface faulting, considering also local deepseated gravitational phenomena (Albano et al., 2016; Aringoli et al., 2016; Huang et al., 2017). 


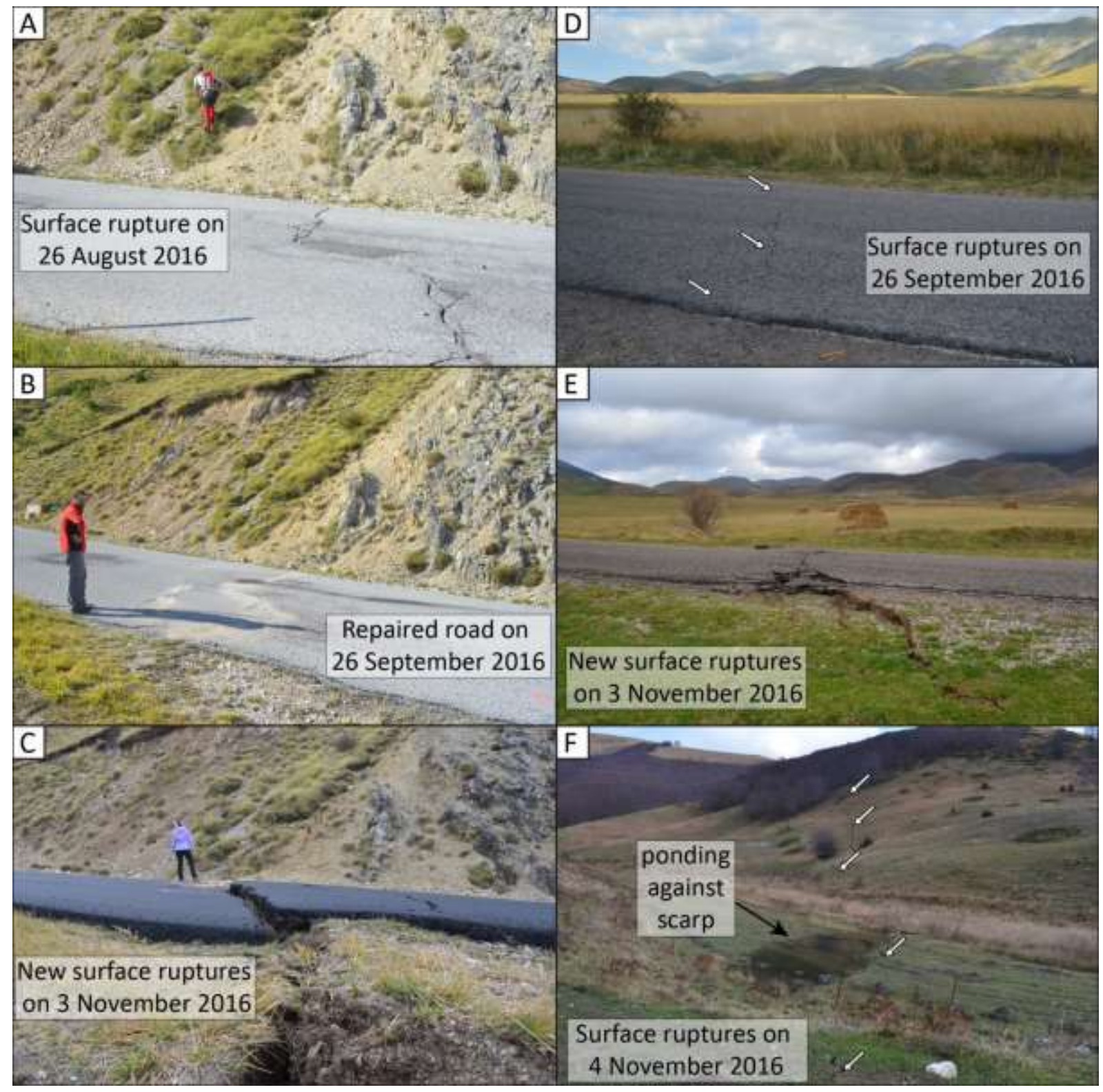

Figure 1: Earthquake environmental effects due to the 2016 earthquake sequence in Central Italy. A) Surface ruptures offset a road in the 24 August, 2016, Amatrice Earthquake (Mw6.2). B) On 26 September, 2016, the road was repaired. C) On 26 October, 2016, the Mw6.6 Norcia Earthquake ruptured the same fault again and offset the re-paved road. $T$ D) Surface ruptures in a road due to the Amatrice Earthquake. E) New surface ruptures were found to offset the road after the Norcia earthquake. This modern example illustrates the pitfalls related to interpreting geological data from palaeo-earthquakes. Looking back a couple of hundreds or even thousands of years, it will be hard or even impossible to distinguish the geological traces of individual moderate earthquakes within a seismogenic zone. Thus, primary offsets used for the reconstruction of palaeo-magnitudes may be misinterpreted. F) Uphill-facing vertical offsets due to the Norcia Earthquake led to ponding in the Castelluccio Plain (photo from 4 November, 2016). In the geological record of palaeo-earthquakes, such features might be preserved as anomalous fine-grained layers in the stratigraphy.

Quaternary geology will have a major opportunity to investigate this issue in the next years, since repeated events like the 2016 ones have left a recognizable footprint in the landscape and in the stratigraphic record. Also, the earthquake series made it possible to observe and distinguish a variety of earthquake environmental effects like primary and secondary ruptures and mass movements. This will provide insights into the distance-magnitude relationships of these EEEs and their occurrence in the case of repeated strong shaking. 


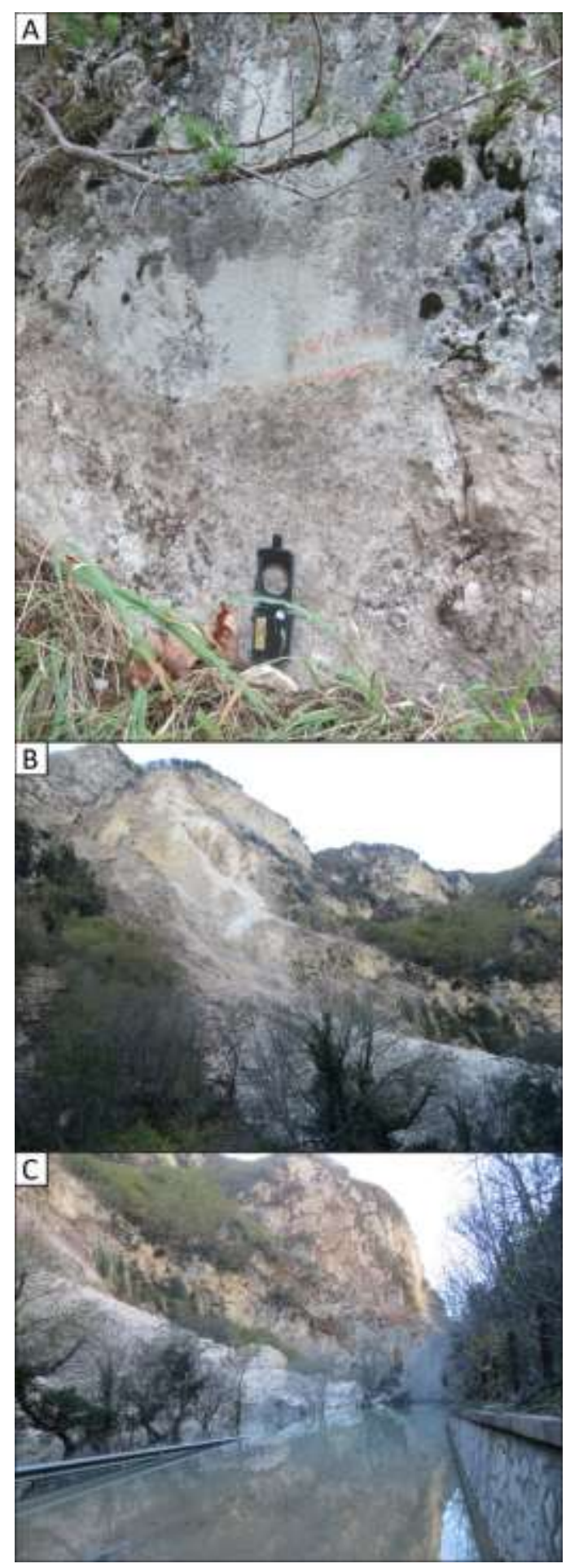

Figure 2: A) The Norcia Earthquake produced offset along limestone fault scarps. B) Secondary earthquake environmental effects of the Norcia Earthquake include, but are not limited to, a number of large mass movements. C) A coseismic landslide blocked a river and led to the formation of a temporal lake (Norcia Earthquake).

The outstanding series of earthquakes in the Central Apennines described above makes clear why novel approaches and interdisciplinary studies on the traces of earthquakes in the Quaternary record are necessary. In fact, they not only allow to understand the tectonic setting of a region - and the Apennines are probably the best example for that in Europe - but they also provide the necessary input data for any evaluation of the seismic hazard (Blumetti and Guerrieri, 2007; IAEA, 2015). The use of palaeoseismological data in seismic hazard assessments can still not be regarded as a matter 
of course, but it is clear that the instrumental period is too short to serve as a reliable database for a region's seismicity. Different approaches to seismic hazard assessment exist and they are all subject to intense discussion. Although probabilistic seismic hazard assessment (PSHA) is a common practise, it is technically impossible to evaluate the success of such approaches today due to the short time span of observation (decades) compared to the earthquake occurrence intervals (centuries to tens of thousands of years). However, it is clear that where earthquakes happened in the past, earthquakes will happen in the future. This is what people can and should be prepared for.

\section{Special Issue Quaternary earthquakes: geology and palaeoseismology for seismic hazard assessment}

The above described example of the Central Apennines clearly illustrates the need to study the Quaternary earthquake record for understanding the overall tectonics and seismic hazard. In order to discuss about earthquake geology in different tectonic and climatic settings, scientists working on Quaternary earthquakes from all over the world annually organise international conferences in the frame of INQUA (namely International Workshops on Palaeoseismology, Active Tectonics and Archaeoseismology - PATA Days). Each conference is hosted in a different part of the world and accompanied by a number of field trips. Typically, the host scientists introduce the international community to the regional geology and explain the research that has been conducted to unravel the earthquake history and the seismic hazard in each region. One of the learning points is how different methods work in different environments, and which site-specific solutions have been developed to study the Quaternary record of earthquakes.

This Special Issue collects contributions in the field of Earthquake Geology and Palaeoseismology from the 6th INQUA International Workshop on Palaeoseismology, Active Tectonics and Archaeoseismology that was held in Fucino, Italy, in April 2015 (http://www.isprambiente.gov.it/it/fucino-2015). The workshop commemorated the centenary of the 1915 Fucino earthquake and included field trips to the active faults in the Central Apennines and palaeoseismological research sites. The meeting was organized by ISPRA, INGV and University of Insubria and promoted by INQUA TERPRO PALACTE which supported the participation of some ECRs from low-GDP countries. Almost 200 scientists from 25 countries have attended the workshop. The scientific program included four main scientific sessions dealing with Quaternary Geology, Palaeoseismology, Archaeoseismology and Seismic and tsunami hazard. About 150 contributions were presented as oral and poster communications. These contributions have been published as extended abstracts in a Special Volume of INGV Miscellanea and are on-line: http://www.ingv.it/editoria/miscellanea/2015/miscellanea27/.

Fifteen selected studies were invited to this Special Issue. The papers deal with palaeoseismology, detailed studies on stratigraphy, innovative techniques to detect earthquakes in the geological record, EEEs, the ESI 2007 scale, and new methods for seismic hazard assessment such as InSAR. We collected papers from Italy, Greece, Spain, Switzerland, the Czech Republic, Austria, and Mexico to show how different settings require a customised set of Quaternary science techniques (Figure 3). Most of the studies concern regions in Europe where active faulting is abundant and where a strong historical record of past earthquakes is available (Figure 4). 


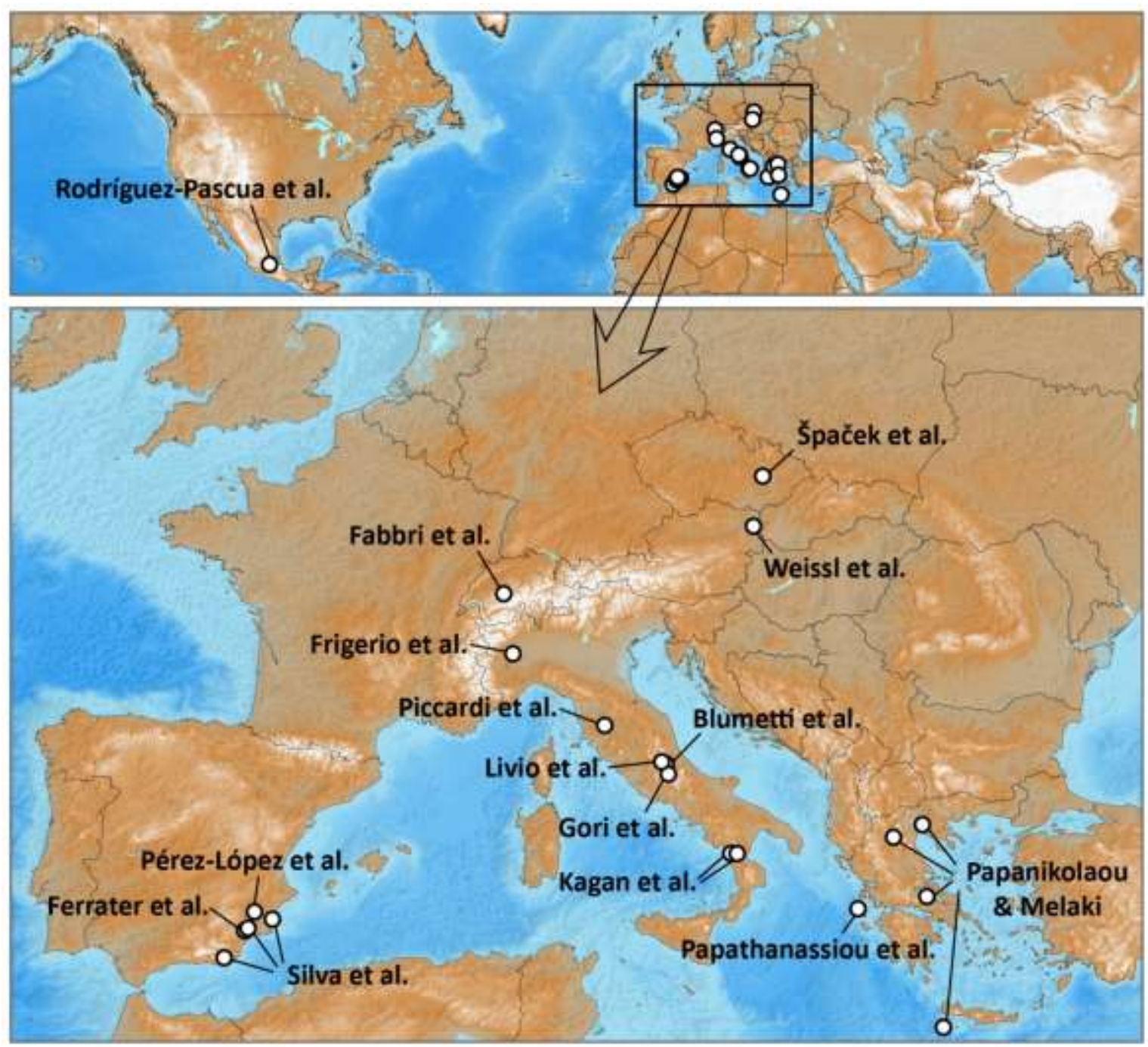

Figure 3: Locations of the studies presented in this Special Volume. Topography and bathymetry are from Etopo1 (Amante and Eakins, 2009). This map is in Mercator projection.

During a microzonation study in San Demetrio ne' Vestini near L'Aquila, an active fault underlying the historical centre was discovered (Working Group MS-AQ, 2010). Whilst the Quaternary evolution of the area was well investigated, an earthquake history based on palaeoseismological data was lacking. The paper by Blumetti et al. in this Special Issue closes this gap with a study on the palaeoseismic history of the San Demetrio ne' Vestini fault. In the Quaternary stratigraphy exposed in a very long trench, the authors found evidence for at least five surface faulting events in the past $18 \mathrm{ka}$ and were able to reconstruct the Holocene earthquake record by retrodeforming the sedimentary layers and colluvial wedges.

Livio et al. analysed the L'Aquila earthquake (6 April, 2009, $M_{w} 6.3$ ) to study distributed surface faulting. The authors analysed the InSAR-derived deformation field of the main event and were able to correlate these data with the location of distributed surface ruptures and the amount of slip associated. They found a significant correlation between the occurrence of distributed faulting and profile curvature of the dislocation field, in spite of the distance from the primary fault. These findings are important for a correct assessment of surface faulting hazard. They allow exploring the possible triggering of slip on secondary faults induced by a main shock on a primary fault. 
Gori et al. investigated a segment of the causative fault of the M7 Fucino event of 1915 and analysed stratigraphic evidence for four earthquakes prior to 1915 in a number of palaeoseismological trenches. In an innovative way they combined classical geological work on the trench stratigraphy with (geo-) archaeological investigations on cultural layers from the Late Neolithic to recent. This enabled the authors to reveal the earthquake history of the past 5,500 years and to reconstruct the interplay between natural and human-induced landscape changes in this region. Their study shows how an interdisciplinary approach encompassing can overcome the limitations of mere palaeoseismological studies.

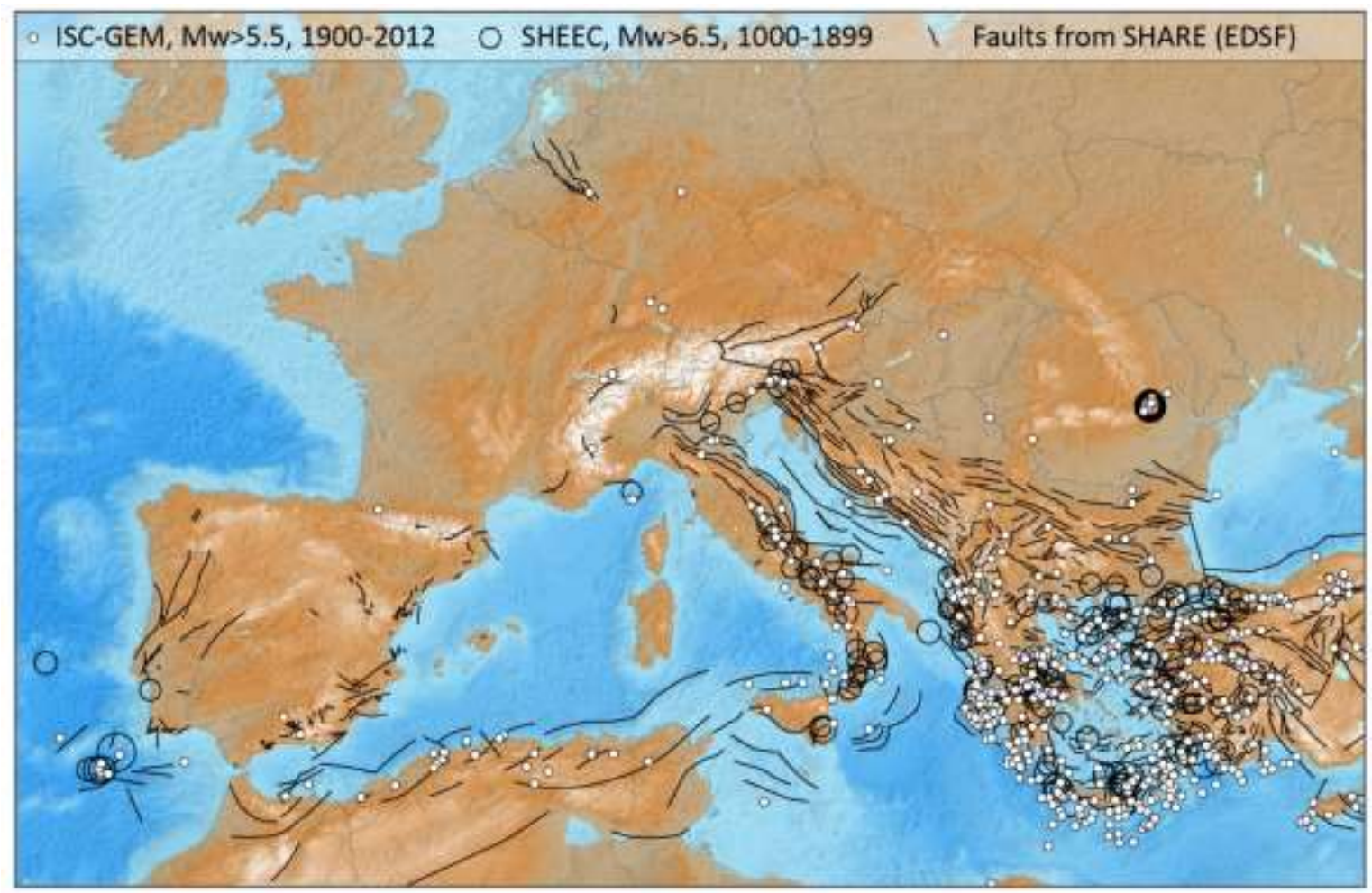

Figure 4: Seismicity and seismogenic faults in Europe and the Mediterranean area. White dots are earthquakes with Mw>5.5 from the ISC-GEM database, 1900-2012 (Storchak et al., 2013); open circles are historical earthquakes with Mw>6.5 from the SHEEC database (Stucchi et al., 2013); black lines are seismogenic faults from the European Database of Seismogenic Faults (Basili et al., 2013). Topography and bathymetry are from Etopo1 (Amante and Eakins, 2009).

Špaček et al. discuss the recent activity of slow-moving faults in the Bohemian Massif through an integrated geophysical and palaeoseismological approach. In their work they considered the concurrent role played by slope deformation processes and differential denudation, which can eventually lead to a geomorphic scarp that resembles a tectonic one. This paper is not only a contribution to the study of palaeoseismic events in what is often referred to as stable continental region, but also highlights challenges for seismic hazard assessments in such slowly-deforming areas.

Weissl et al. provide multiple field evidence from the Quaternary Gänserndorf Terrace situated north of Vienna. Their researches led to demonstrate the tectonic segmentation of a former much larger river terrace. Luminescence ages (IRSL and OSL) allowed dating the terrace formation as well as the rate of tectonic subsidence. Furthermore, this paper deals with the geomorphology of the terrace surface and the adjacent basins and it discusses dry valleys and large depressions visible in the digital elevation model as a result of permafrost processes. Therefore, this paper demonstrates that both neotectonics and glacial processes have formed the recent landforms of this area. 
Assessing the seismogenic potential of active faults in high heat-flow environments can be particularly challenging and needs, as a first step, the characterization of geometry and slip rates of the recognized faults, together with the characterisation of associated geothermal manifestations. Piccardi et al. analysed the Tuscany - northern Latium region (Central Italy) by means of DTM analysis, field surveys and the review of a large amount of published literature studies, in order to propose a first systematic characterisation of the structures present in this region.

Ferrater et al. provide a study aimed at defining the seismic potential of the left-lateral strike-slip Alhama de Murcia fault (SE Iberian Peninsula) based on palaeoseismic investigations combined with morphotectonic analyses. Results have shown that the studied fault is one of the most active faults in the Eastern Betics Shear Zone in terms of slip rate. Their integrated approach is recommended especially for faults with scarce evidence of late Holocene slip.

Frigerio et al. present a multidisciplinary field study in the Eastern Monferrato Arc aiming at individuating palaeoseismic evidence of recent strong earthquakes. Through the integration of sedimentological and micropedological data with structural analyses, it has been possible to point out the evidence of several reverse surface faulting and warping events, that allow to state that the Monferrato Arc, similarly to other thrust faults in the Po Plain, is now a seismic gap but it is capable of strong earthquakes (Mmax 6.5) with long recurrence intervals.

Waterside areas can be particularly promising for palaeoseismology since one can benefit also from offshore high-resolution data, including coring, seismic reflection profiles, and bathymetry. Fabbri et al. analysed a combined database in the Bernese Alps (Switzerland), close to Lake Thun, including offshore seismic reflection profiles, HR bathymetry, onshore GPR, and field data collection. Their observations confirm a Holocene re-activation of a fault without known historical or instrumental events according to seismic catalogues. This study highlights the value of palaeoseismic investigations in areas with long earthquake recurrence intervals and low seismicity, and it is a great example for the additional power of a multi-method approach.

Four papers are dealing with the ESIO7 scale (Michetti et al., 2007; Serva et al., 2015), an intensity scale developed in the frame of INQUA that is based only on the characteristics and size of earthquake environmental effects. This scale has been applied by Papathanassiou et al. to the 2014 Jan. $26^{\text {th }}$ and Feb. $3^{\text {rd }}$ Cephalonia earthquakes (Greece). Several coseismic environmental effects were recorded, mainly liquefaction and slope failures, while no significant structural damages occurred. Through the application of the ESI07 scale it was possible to evaluate the 2014 intensity that was comparable with the 1867 earthquake, even if this historical event was lower in terms of magnitude. This result has confirmed the relevance of earthquake environmental effects for a proper seismic hazard assessment since they allow maintaining the consistency with the historical catalogues.

Papanikolau and Melaki have used the ESI07 scale to analyse four events in Greece that occurred recently (1995 Ms6.6 Kozani-Grevena and $1978 \mathrm{M}_{w} 6.5$ Thessaloniki earthquakes) and in historical times (1894 M6.8 Atalanti and 365AD Mw8.4 Crete earthquakes). A strong record of earthquake environmental effects is available for all these earthquakes, including surface faulting as well as secondary effects. The results have been integrated with other ESIO7 applications in Greece and in the Mediterranean with the aim to i) define relationships between magnitude and the ESIO7 intensities; ii) offer a preliminary estimate of how the intensity attenuates with distance. 
The ESI07 scale has been applied by Rodríguez-Pascua et al. to the 1912 Acambay Earthquake (M6.9, Mexico). The authors determined the epicenter of this earthquake analysing earthquake archaeological effects (EAEs) and earthquake environmental effects (EEEs). Moreover, they introduced a new interpretation of the genesis of the earthquake environmental effects. Additionally, they have estimated the total rupture length and the potential seismicity of the Acambay-Tixmadeje fault zone.

Silva et al. applied the ESIO7 scale to three earthquakes which occurred in the Betic Cordillera, SE Spain (2011 Lorca, 1863 Huércal-Overa, and 1829 Torrevieja) with the aim to obtain high-resolution ShakeMaps scenarios based on the characteristics and the spatial distribution of EEEs. The resulting maps provide more realistic scenarios than those resulting from damage based EMS macroseismic data, leading to a better definition of the geological parameters of the earthquake (e.g., the characteristics and size of the seismic source).

Two papers presented in this Special Issue deal with spelaeoseismology and evidence for earthquakes from caves. The first contribution, by Pérez-López et al., deals with a classical palaeoseismic analysis of active faulting combined with thermal analysis of the uppermost part of the crust. The authors have used deep caves (300 m depth) to obtain the vertical thermal gradient by direct measurements. They also described the air quality in the caves, seeking for the relationship between gas emission and tectonic activity. The novelty of the methodology is the combination between palaeoseismology and geothermics for the estimation of the Quaternary tectonic slip-rate of active faults. Moreover, the authors dated the last earthquake from the analysis of the remains of bones of Lynx pardinus spelaeus found in the cave.

The second contribution, by Kagan et al., is the study of damaged spelaeothems in Calabrian caves as evidence for earthquakes. The authors found evidence for earthquakes in two caves (Romito and San Paolo caves), that they documented, sampled, and subsequently dated by the state-of-the-art U-Th series method. Their results contribute to the understanding of the recurrence of damaging earthquakes in the Calabrian region. This is finalised to the seismic hazard assessment in the earthquake-prone Apennines region, characterized by a long-term recurrence pattern. Here more than 100,000 people are potentially exposed to earthquake shaking and historical data clearly underestimates the risk. To our knowledge, this is the first report showing this long term, well-dated, palaeoseismic record.

\section{Acknowledgements}

We wish to thank all authors for their contributions to this Special Issue. We are indebted to QI editor Min-Te Chen and associate editor Asfawossen Asrat for making this Special Issue happen. The organisers of the Fucino 2015 did a great job in bringing together scientists from all over the world in Italy - grazie mille! INQUA, the TERPRO commission, the former IFG PALACTE and the new IFG EGSHaz are acknowledged for their continuous support of the palaeoseismology and earthquake geology community. 


\section{References}

Albano, M., Saroli, M., Moro, M., Falcucci, E., Gori, S., Stramondo, S., Galadini, F. and Barba, S., 2016. Minor shallow gravitational component on the Mt. Vettore surface ruptures related to MW 6, 2016 Amatrice earthquake. Annals of Geophysics, 59, doi:10.4401/ag-7299.

Alessio, G., Alfonsi, L., Brunori, C. A., Cinti, F. R., Civico, R., Cucci, L., D’Addezio, G., De Ritis, R., Falcucci, E., Fracassi, U., Gasparini, A., Gori, S., Lisi, A., Mariano, S., Mariucci, M.T., Montone, P., Nappi, R., Pantosti, D., Patera, A., Pierdominici, S., Pignone, M., Pinzi, S., Pucci, S., Vannoli, P., Venuti, A., and Villani, F. (EMERGEO INGV Prompt Geological Survey Team), 2009. Evidence for surface rupture associated with the Mw 6.3 L'Aquila earthquake sequence of April 2009 (central Italy). Terra Nova. 22(1), 43-51.

Amante, C., and Eakins, B.W., 2009. ETOPO1 1 Arc-Minute Global Relief Model: Procedures, Data Sources and Analysis. NOAA Technical Memorandum NESDIS NGDC-24. National Geophysical Data Center, NOAA. doi:10.7289/V5C8276M, accessed 2016-12-21.

Ambraseys, N. N., 1971. Value of historical records of earthquakes. Nature, 232, 375-379.

Ambraseys, N. N., 1983. Notes on historical seismicity. Bulletin of the Seismological Society of America, 73(6A), 1917-1920.

Aringoli, D., Farabollini, P., Giacopetti, M., Materazzi, M., Paggi, S., Pambianchi, G., Pierantoni, P., Pistolesi, E., Pitts, A. and Tondi, E., 2016. The August 24th 2016 Accumoli earthquake: surface faulting and Deep-Seated Gravitational Slope Deformation (DSGSD) in the Monte Vettore area. Annals of Geophysics, 59, doi:10.4401/ag-7199.

Arrowsmith, J. R., and Zielke, O., 2009. Tectonic geomorphology of the San Andreas Fault zone from high resolution topography: an example from the Cholame segment. Geomorphology, 113(1), 70-81.

Azzaro, R., Ferreli, L., Michetti, A. M., Serva, L., and Vittori, E., 1998. Environmental Hazard of Capable Faults: The Case of the Pernicana Fault (Mt. Etna, Sicily). Natural Hazards, 17(2), 147-162.

Basili R., Kastelic V., Demircioglu M. B., Garcia Moreno D., Nemser E. S., Petricca P., Sboras S. P., Besana-Ostman G. M., Cabral J., Camelbeeck T., Caputo R., Danciu L., Domac H., Fonseca J., GarcíaMayordomo J., Giardini D., Glavatovic B., Gulen L., Ince Y., Pavlides S., Sesetyan K., Tarabusi G., Tiberti M. M., Utkucu M., Valensise G., Vanneste K., Vilanova S., and Wössner J., 2013. The European Database of Seismogenic Faults (EDSF) compiled in the framework of the Project SHARE. http://diss.rm.ingv.it/share-edsf/, doi: 10.6092/INGV.IT-SHARE-EDSF.

Bemis, S. P., Micklethwaite, S., Turner, D., James, M. R., Akciz, S., Thiele, S. T., and Bangash, H. A., 2014. Ground-based and UAV-based photogrammetry: A multi-scale, high-resolution mapping tool for structural geology and paleoseismology. Journal of Structural Geology, 69, 163-178.

Benedetti, L. C., and Van Der Woerd, J., 2014. Cosmogenic nuclide dating of earthquakes, faults, and toppled blocks. Elements, 10(5), 357-361.

Bindi, D., Luzi, L., Pacor, F., Franceschina, G., and Castro, R. R., 2006. Ground-motion predictions from empirical attenuation relationships versus recorded data: the case of the 1997-1998 Umbria- 
Marche, central Italy, strong-motion data set. Bulletin of the Seismological Society of America, 96(3), 984-1002.

Blumetti, A. M., Michetti, A. M., and Serva, L., 1988. The ground effects of the Fucino earthquake of Jan. 13th, 1915; an attempt for the understanding of recent geological evolution of some tectonic structures. Historical Seismicity of Central Eastern Mediterranean Region, Proceedings of the 1987 ENEA-IAEA International Workshop. Ente per le Nuove Tecnol., I'Energia, e l'Ambiente, Rome, 297319.

Blumetti, A. M., Dramis, F., and Michetti, A. M., 1993. Fault-generated mountain fronts in the central Apennines (Central Italy): Geomorphological features and seismotectonic implications. Earth Surface Processes and Landforms, 18(3), 203-223.

Blumetti, A.M., 1995. Neotectonic investigations and evidence of paleoseisimicity in the epicentral area of the January-February 1703 Central Italy earthquakes. Bulletin of the American Association of Engineering Geologists, Special Volume n. 6: "Perspectives in Paleoseismology", Texas A\&M University, Chapter 7, 83-100.

Blumetti, A.M., and Guerrieri, L., 2007. Fault-generated mountain fronts and the identification of fault segments: implications for seismic hazard assessment. Boll. Soc. Geol. It. (Ital. J. Geosci.), 126(2), 307-321.

Blumetti, A. M., Guerrieri, L., and Vittori, E., 2013. The primary role of the Paganica-San Demetrio fault system in the seismic landscape of the Middle Aterno Valley basin (Central Apennines). Quaternary International, 288, 183-194.

Boncio, P., Pizzi, A., Brozzetti, F., Pomposo, G., Lavecchia, G., Di Naccio, D., and Ferrarini, F., 2010. Coseismic ground deformation of the 6 April 2009 L'Aquila earthquake (central Italy, Mw6. 3). Geophysical Research Letters, 37(6), doi: 10.1029/2010GL042807.

Bull, W. B., 2007. Tectonic geomorphology of mountains: a new approach to paleoseismology. WileyBlackwell, Malden, USA.

Campbell, G. E., Walker, R. T., Abdrakhmatov, K., Jackson, J., Elliott, J. R., Mackenzie, D., Middleton, T., and Schwenninger, J. L., 2015. Great earthquakes in low strain rate continental interiors: An example from SE Kazakhstan. Journal of Geophysical Research: Solid Earth, 120(8), 5507-5534.

Cello, G., Mazzoli, S., Tondi, E., and Turco, E., 1997. Active tectonics in the central Apennines and possible implications for seismic hazard analysis in peninsular Italy. Tectonophysics, 272(1), 43-68.

Cello, G., Deiana, G.,Mangano, P.,Mazzoli, S., Tondi, E., Ferreli, L.,Maschio, L.,Michetti, A.M., Serva, L., and Vittori, E., 1998. Evidence of surface faulting during the September 26, 1997, Colfiorito (Central Italy) earthquakes. J. Earthqu. Eng. 2, 303-324.

Cheloni, D., D'agostino, N., D'anastasio, E., Avallone, A., Mantenuto, S., Giuliani, R., Mattone, M., Calcaterra, S., Gambino, P., Dominici, D., Radicioni, F., and Fastellini, G., 2010. Coseismic and initial post-seismic slip of the $2009 \mathrm{Mw} 6.3$ L'Aquila earthquake, Italy, from GPS measurements. Geophysical Journal International, 181(3), 1539-1546. 
Cheloni, D., Serpelloni, E., Devoti, R., D'Agostino, N., Pietrantonio, G., Riguzzi, F., Anzidei, M., Avallone, A., Cavaliere, A., Cecere, G., D'Ambrosio, C., Esposito, A., Falco, L., Galvani, A., Selvaggi, G., Sepe, V., Calcaterra, S., Giuliani, R., Mattone, M., Gambino, P., Abruzzese, L., Cardinale, V., Castagnozzi, A., De Luca, G., Massucci, A., Memmolo, A., Migliari, F., Minichiello, F. and Zarrilli, L., 2016. GPS observations of coseismic deformation following the 2016, August 24, Mw 6 Amatrice earthquake (central Italy): data, analysis and preliminary fault model. Annals Of Geophysics, 59, doi:10.4401/ag-7269.

Chiarabba, C., Amato, A., Anselmi, M., Baccheschi, P., Bianchi, I., Cattaneo, M., Cecere, G., Chiaraluce, L., Ciaccio, M. G., De Gori, P., De Luca, G., Di Bona, M., Di Stefano, R., Faenza, L., Govoni, A., Improta, L., Lucente, F. P., Marchetti, A., Margheriti, L., Mele, F., Michelini, A., Monachesi, G., Moretti, M., Pastori, M., Piana Agostinetti, N., Piccinini, D., Roselli, P., Seccia, D., and Valoroso, L., 2009. The 2009 L'Aquila (central Italy) Mw6. 3 earthquake: Main shock and aftershocks. Geophysical Research Letters, 36(18).

Chiaraluce, L., 2012. Unravelling the complexity of Apenninic extensional fault systems: A review of the 2009 L'Aquila earthquake (Central Apennines, Italy). Journal of Structural Geology, 42, 2-18.

Cinque A., Patacca E., Scandone P., and Tozzi M., 1991. Quaternary kinematic evolution of the Southern Apennines. Relationship between surface geological features and deep lithospheric structures. Annals of Geophysics, 36(2), 249-260.

Cinti, F. R., Cucci, L., Marra, F., and Montone, P., 2000. The 1997 Umbria-Marche earthquakes (Italy): relation between the surface tectonic breaks and the area of deformation. Journal of Seismology, $4(4), 333-343$.

Cinti, F. R., Pantosti, D., De Martini, P. M., Pucci, S., Civico, R., Pierdominici, S., Cucci, L., Brunori, C. A., Pinzi, S., and Patera, A., 2011. Evidence for surface faulting events along the Paganica fault prior to the 6 April 2009 L'Aquila earthquake (central Italy). Journal of Geophysical Research: Solid Earth, 116(B7).

Cocco, M., Cultrera, G., Amato, A., Braun, T., Cerase, A., Margheriti, L., Bonaccorso, A., Demartin, M., De Martini, P., Galadini, F., Meletti, C., Nostro, C., Pacor, F., Pantosti, D., Pondrelli, S., Quareni, F., and Todesco, M., 2015. The L'Aquila trial. Geological Society, London, Special Publications, 419(1), 43-55.

Dahle, A., Bungum, H., and Kvamme, L. B., 1990. Attenuation models inferred from intraplate earthquake recordings. Earthquake Engineering and Structural Dynamics, 19(8), 1125-1141.

DeLong, S. B., Donnellan, A., Ponti, D. J., Rubin, R. S., Lienkaemper, J. J., Prentice, C. S., Dawson, T. E., Seitz, G., Schwartz, D. P., Hudnut, K. W., Rosa, C., Pickering, A., and Parker, J. W., 2016. Tearing the terroir: Details and implications of surface rupture and deformation from the 24 August 2014 M6. 0 South Napa earthquake, California. Earth and Space Science, 3(10), 416-430.

d'Oreye, N., González, P. J., Shuler, A., Oth, A., Bagalwa, L., Ekström, G., Kavotha, D., Kervyn, F., Lucas, C., Lukaya, F., Osodundu, E., Wauthier, C., and Fernández, J., 2011. Source parameters of the 2008 Bukavu-Cyangugu earthquake estimated from InSAR and teleseismic data. Geophysical Journal International, 184(2), 934-948. 
Dramis, F., and Blumetti, A. M., 2005. Some considerations concerning seismic geomorphology and paleoseismology. Tectonophysics, 408(1), 177-191.

Elliott, J. R., Copley, A. C., Holley, R., Scharer, K., and Parsons, B., 2013. The 2011 Mw 7.1 Van (Eastern Turkey) earthquake. Journal of Geophysical Research: Solid Earth, 118(4), 1619-1637.

Elliott, J. R., Walters, R. J., and Wright, T. J., 2016. The role of space-based observation in understanding and responding to active tectonics and earthquakes. Nature communications, 7 , 13844.

EMERGEO Working group: Pucci, S., De Martini, P., Civico, R., Nappi, R., Ricci, T., Villani, F., Brunori, C., Caciagli, M., Sapia, V., Cinti, F., Moro, M., Di Naccio, D., Gori, S., Falcucci, E., Vallone, R., Mazzarini, F., Tarquini, S., Del Carlo, P., Kastelic, V., Carafa, M., De Ritis, R., Gaudiosi, G., Nave, R., Alessio, G., Burrato, P., Smedile, A., Alfonsi, L., Vannoli, P., Pignone, M., Pinzi, S., Fracassi, U., Pizzimenti, L., Mariucci, M., Pagliuca, N., Sciarra, A., Carluccio, R., Nicolosi, I., Chiappini, M., D’Ajello Caracciolo, F., Pezzo, G., Patera, A., Azzaro, R., Pantosti, D., Montone, P., Saroli, M., Lo Sardo, L. and Lancia, M., 2016. Coseismic effects of the 2016 Amatrice seismic sequence: first geological results. Annals of Geophysics, 59, doi:10.4401/ag-7195.

Fielding, E. J., Lundgren, P. R., Taymaz, T., Yolsal-Çevikbilen, S., and Owen, S. E., 2013. Fault-Slip Source Models for the 2011 M 7.1 Van Earthquake in Turkey from SAR Interferometry, Pixel Offset Tracking, GPS, and Seismic Waveform Analysis. Seismological Research Letters, 84(4), 579-593.

Fletcher, J. M., Teran, O. J., Rockwell, T. K., Oskin, M. E., Hudnut, K. W., Mueller, K. J., Spelz, R. M., Akciz, S. O., Masana, E., Faneros, G., Fielding, E. J., Leprince, S., Morelan, A. E., Stock, J., Lynch, D. K., Elliott, A. J., Gold, P., Liu-Zeng, J., González-Ortega, A., Hinojosa-Corona, A., and González-García, J., 2014. Assembly of a large earthquake from a complex fault system: Surface rupture kinematics of the 4 April 2010 El Mayor-Cucapah (Mexico) Mw 7.2 earthquake. Geosphere, 10(4), 797-827.

Galadini, F., and Galli, P., 1999. The Holocene paleoearthquakes on the 1915 Avezzano earthquake faults (central Italy): implications for active tectonics in the central Apennines. Tectonophysics, 308(1), 143-170.

Galadini, F., and Galli, P., 2000. Active tectonics in the central Apennines (Italy)-input data for seismic hazard assessment. Natural Hazards, 22(3), 225-268.

Galadini, F,. and Galli, P., 2003. Paleoseismology of silent faults in the Central Apennines (Italy): the Mt. Vettore and Laga Mts. faults. Annals of Geophysics, 46(5), 815-836.

Galadini, F., Hinzen, K. G., and Stiros, S., 2006. Archaeoseismology: methodological issues and procedure. Journal of Seismology, 10(4), 395-414.

Galli, P., Bosi, V., Galadini, F., Meghraoui, M., Messina, P., Basili, R., Moro, M., and Sposato, A., 1998. Evidenze tettoniche di superficie connesse ai terremoti umbro-marchigiano del settembre-ottobre 1997. Ingegneria Sismica, anno XV, n 1, gennaio-aprile 1998.

Galli, P., Galadini, F., and Pantosti, D., 2008. Twenty years of paleoseismology in Italy. Earth-Science Reviews, 88(1), 89-117. 
Galli, P., Giaccio, B., and Messina, P., 2010. The 2009 central Italy earthquake seen through 0.5 Myrlong tectonic history of the L'Aquila faults system. Quaternary Science Reviews, 29(27), 3768-3789.

Galli, P. A., Giaccio, B., Messina, P., Peronace, E., and Zuppi, G. M., 2011. Palaeoseismology of the L'Aquila faults (central Italy, 2009, Mw 6.3 earthquake): implications for active fault linkage.

Geophysical Journal International, 187(3), 1119-1134.

Galli, P., Giaccio, B., Messina, P., and Peronace, E., 2016. Three magnitude 7 earthquakes on a single fault in central Italy in 1400 years, evidenced by new palaeoseismic results. Terra Nova, 28(2), 146154.

Giaccio, B., Galli, P., Messina, P., Peronace, E., Scardia, G., Sottili, G., Sposado, A., Chiarini, E., Jicha, B., and Silvestri, S., 2012. Fault and basin depocentre migration over the last $2 \mathrm{Ma}$ in the L'Aquila 2009 earthquake region, central Italian Apennines. Quaternary Science Reviews, 56, 69-88.

Gold, P. O., Oskin, M. E., Elliott, A. J., Hinojosa-Corona, A., Taylor, M. H., Kreylos, O., and Cowgill, E., 2013. Coseismic slip variation assessed from terrestrial LiDAR scans of the El Mayor-Cucapah surface rupture. Earth and Planetary Science Letters, 366, 151-162.

Gregory, L. C., Thomas, A. L., Walker, R. T., Garland, R., Mac Niocaill, C., Fenton, C. R., Bayasgalan, A., Amgaa, T., Gantulga, B., Xu, S., Schnabel, C., and West, A. J., 2014. Combined uranium series and 10 Be cosmogenic exposure dating of surface abandonment: A case study from the Ölgiy strike-slip fault in western Mongolia. Quaternary Geochronology, 24, 27-43.

Grützner, C., Barba, S., Papanikolaou, I., and Pérez-López, R., 2013. Earthquake geology: science, society and critical facilities. Annals of Geophysics, 56(6), S0683.

Grützner, C., Fischer, P., and Reicherter, K., 2016. Holocene surface ruptures of the Rurrand Fault, Germany-insights from palaeoseismology, remote sensing and shallow geophysics. Geophys. J. Int. 204, 1662-1677.

Grützner, C., Carson, E., Walker, R. T., Rhodes, E. J., Mukambayev, A., Mackenzie, D., Elliott, J. R., Campbell, G. E., and Abdrakhmatov, K., 2017. Assessing the activity of faults in continental interiors: palaeoseismic insights from SE Kazakhstan. Earth and Planetary Science Letters, 459(1), 93-104.

Guerrieri L., Blumetti A.M., Esposito E., Michetti A.M., Porfido S., Serva L., Tondi E., and Vittori E., 2009. Capable faulting, environmental effects and seismic landscape in the area affected by the 1997 Umbria-Marche (Central Italy) seismic sequence. Tectonophysics, 476 (1), 269-281.

Hartzell, S. H., and Heaton, T. H., 1983. Inversion of strong ground motion and teleseismic waveform data for the fault rupture history of the 1979 Imperial Valley, California, earthquake. Bulletin of the Seismological Society of America, 73(6A), 1553-1583.

Haugerud, R. A., Harding, D. J., Johnson, S. Y., Harless, J. L., Weaver, C. S., and Sherrod, B. L., 2003. High-resolution lidar topography of the Puget Lowland, Washington. GSA Today, 13(6), 4-10.

Huang, M. H., Fielding, E. J., Liang, C., Milillo, P., Bekaert, D., Dreger, D. and Salzer, J., 2017. Coseismic deformation and triggered landslides of the $2016 \mathrm{Mw} 6.2$ Amatrice earthquake in Italy. Geophysical Research Letters. doi: 10.1002/2016GL071687. 
IAEA, 2015. The Contribution of Palaeoseismology to Seismic Hazard Assessment in Site Evaluation for Nuclear Installations. International Atomic Energy Agency, Vienna. IAEA-TECDOC series, ISSN 1011-4289, no. 1767; ISBN 978-92-0-105415-9.

Jackson, J., and McKenzie, D., 1984. Active tectonics of the Alpine-Himalayan Belt between western Turkey and Pakistan. Geophysical Journal International, 77(1), 185-264.

Koto, B., 1893. On the cause of the great earthquake in central Japan, 1891. J. Coll. Sci. Imp. Univ. Tokyo, 5, 295-353.

Lario, J., Bardaji, T., Silva, P. G., Zazo, C., and Goy, J. L., 2016. Improving the coastal record of tsunamis in the ESI-07 Scale: Tsunami Environmental Effects Scale (TEE-16 Scale). Geologica Acta, 13(4).

Lavecchia, G., Castaldo, R., de Nardis, R., De Novellis, V., Ferrarini, F., Pepe, S., Brozzetti, F., Solaro, G., Cirillo, D., Bonano, M., Boncio, P., Casu, F., De Luca, C., Lanari, R., Manunta, M., Manzo, M., Pepe, A., Zinno I., and Tizzani P., 2016. Ground deformation and source geometry of the 24 August 2016 Amatrice earthquake (Central Italy) investigated through analytical and numerical modeling of DInSAR measurements and structural-geological data. Geophys. Res. Lett., 43, 12,389-12,398.

Liu, M., and Stein, S., 2016. Mid-continental earthquakes: Spatiotemporal occurrences, causes, and hazards. Earth-Science Reviews, 162, 364-386.

Livio, F., Michetti, A., Vittori, E., Gregory, L., Wedmore, L., Piccardi, L., Tondi, E., Roberts, G., W.G., C., Blumetti, A., Bonadeo, L., Brunamonte, F., Comerci, V., Di Manna, P., Ferrario, M., Walker, J., Frigerio, C., Fumanti, F., Guerrieri, L., lezzi, F., Leoni, G., McCaffrey, K., Mildon, Z., Phillips, R., Rhodes, E., Walters, R., and Wilkinson, M., 2016. Surface faulting during the August 24, 2016, central Italy earthquake (Mw 6.0): preliminary results. Annals of Geophysics, 59, doi:10.4401/ag-7197.

Maggi, A., Jackson, J. A., Priestley, K., and Baker, C., 2000. A re-assessment of focal depth distributions in southern Iran, the Tien Shan and northern India: Do earthquakes really occur in the continental mantle?. Geophysical Journal International, 143(3), 629-661.

McCalpin, J. P., 2009. Paleoseismology (Ed.). Academic press, New York, vol. 95.

Meletti, C., Visini, F., D'Amico, V., and Rovida, A., 2016. Seismic hazard in Central Italy and the 2016 Amatrice earthquake. Annals of Geophysics, 59, doi:10.4401/ag-7248.

Messina, P., Galadini, F., Galli, P., Sposato, A., 2002. Quaternary basin evolution and present tectonic regime in the area of the 1997-1998 Umbria-Marche seismic sequence (central Italy).

Geomorphology 42, 97-116.

Michele, M., Di Stefano, R., Chiaraluce, L., Cattaneo, M., De Gori, P., Monachesi, G., Latorre, D., Marzorati, S., Valoroso, L., Ladina, C., Chiarabba, C., Lauciani, V., and Fares, M., 2016. The Amatrice 2016 seismic sequence: a preliminary look at the mainshock and aftershocks distribution. Annals of Geophysics, 59. doi:10.4401/ag-7227.

Michetti, A. M., Brunamonte, F., Serra, L., and Vittori, E., 1996. Trench investigations of the 1915 Fucino earthquake fault scarps (Abruzzo, central Italy): Geological evidence of large historical events. Journal of Geophysical Research, 101(B3), 5921-5936. 
Michetti, A. M., Audemard M., F. A., and Marco, S., 2005. Future trends in paleoseismology: Integrated study of the seismic landscape as a vital tool in seismic hazard analyses. Tectonophysics, 408(1), 3-21.

Michetti, A. M., Esposito, E., Guerrieri, L., Porfido, S., Serva, L., Tatevossian, R., Vittori, E., Audemard, F., Azuma, T., Clague, J., Comerci, V., Gurpinar, A., McCalpin, J., Mohammadioun, B., Morner, N.A., Ota, Y., and Rogozhin, E., 2007. Intensity Scale ESI 2007. Memorie Descrittive Carta Geologica d'Italia, $74,53 \mathrm{pp}$.

Michetti, A., Giardina, F., Livio, F., Mueller, K., Serva, L., Sileo, G., Vittori, E., Devoti, R., Riguzzi, F., Carcano, C., Rogledi, S., Bonadeo, L., Brunamonte, F., and Fioraso, G., 2012. Active compressional tectonics, Quaternary capable faults, and the seismic landscape of the Po Plain ( $\mathrm{N}$ Italy). Annals of Geophysics 55(5), doi: 10.4401/ag-5462.

Middleton, T. A., Walker, R. T., Rood, D. H., Rhodes, E. J., Parsons, B., Lei, Q., Elliott, J. R., Ren, Z., and Zhou, Y., 2016. The tectonics of the western Ordos Plateau, Ningxia, China: slip rates on the Luoshan and East Helanshan Faults. Tectonics, 35(11), 2754-2777.

Moreiras, S. M., and Páez, M. S., 2015. Historical damage and earthquake environmental effects related to shallow intraplate seismicity of central western Argentina. Geological Society, London, Special Publications, 399(1), 369-382.

Nikonov, A. A., 1995. The stratigraphic method in the study of large past earthquakes. Quaternary International, 25, 47-55.

Noller, J. S., 2001. Archaeoseismology. In: Earth Sciences and Archaeology (pp. 143-170). Springer US.

Oddone, E., 1915. Gli elementi fisici del grande terremoto marsicano-fucense. Bollettino della Società Sismologica Italiana, 19, 71-291.

Oskin, M. E., Arrowsmith, J. R., Corona, A. H., Elliott, A. J., Fletcher, J. M., Fielding, E. J., Gold, P.O., Gonzalez Garcia, J. J., Hudnut, K. W., Liu-Zeng, J., and Teran, O. J., 2012. Near-field deformation from the El Mayor-Cucapah earthquake revealed by differential LIDAR. Science, 335(6069), 702-705.

Pantosti, D., D'Addezio, G., and Cinti, F. R., 1996. Paleoseismicity of the Ovindoli-Pezza fault, central Apennines, Italy: A history including a large, previously unrecorded earthquake in the Middle Ages (860-1300 AD). Journal of Geophysical Research: Solid Earth, 101(B3), 5937-5959.

Papanikolaou, I. D., 2011. Uncertainty in intensity assignment and attenuation relationships: How seismic hazard maps can benefit from the implementation of the Environmental Seismic Intensity scale (ESI 2007). Quaternary International, 242(1), 42-51.

Papanikolaou, I. D., Van Balen, R., Silva, P. G., and Reicherter, K., 2015. Geomorphology of active faulting and seismic hazard assessment: New tools and future challenges. Geomorphology, 237, 1-13.

Philip, H., and Meghraoui, M., 1983. Structural analysis and interpretation of the surface deformations of the El Asnam earthquake of October 10, 1980. Tectonics, 2(1), 17-49.

Porfido, S., Esposito, E., Spiga, E., Sacchi, M., Molisso, F., and Mazzola, S., 2015. Impact of Ground Effects for an appropriate mitigation strategy in seismic area: the example of Guatemala 1976 
earthquake. In: Engineering Geology for Society and Territory-Volume 2 (pp. 703-708). Springer International Publishing.

Prentice, C.S., Kendrick, K., Berryman, K., Bayasgalan, A., Ritz, J.F., and Spencer, J.Q., 2002. Prehistoric ruptures of the Gurvan Bulag fault, Gobi Altay, Mongolia. J. Geophys. Res., Solid Earth107 (B12).

Pucci, S., Civico, R., Villani, F., Ricci, T., Delcher, E., Finizola, A., Sapia, V., De Martini, P. M., Pantosti, D., Barde-Cabusson, S., Brothelande, E., Gusset, R., Mezon, C., Orefice, S., Peltier, A., Poret, M., Torres, L., and Suski, B., 2016. Deep electrical resistivity tomography along the tectonically active Middle Aterno Valley (2009 L'Aquila earthquake area, central Italy). Geophysical Journal International, 207(2), 967-982.

Pucci, S., De Martini, P. M., Civico, R., Villani, F., Nappi, R., Ricci, T., Azzaro, R., Brunori, C. A., Caciagli, M., Cinti, F. R., Sapia, V., De Ritis, R., Mazzarini, F., Tarquini, S., Gaudiosi, G., Nave, R., Alessio, G., Smedile, A., Alfonsi, L., Cucci, L., and Pantosti, D., 2017. Coseismic ruptures of the 24 August 2016, Mw 6.0 Amatrice earthquake (central Italy), Geophys. Res. Lett., 44, doi:10.1002/2016GL071859.

Quigley, M. C., Hughes, M. W., Bradley, B. A., van Ballegooy, S., Reid, C., Morgenroth, J., Horton, T., Duffy, B., and Pettinga, J. R., 2016. The 2010-2011 Canterbury earthquake sequence: Environmental effects, seismic triggering thresholds and geologic legacy. Tectonophysics, 672, 228-274.

Reicherter, K., Michetti, A. M., and Barroso, P. S., 2009. Palaeoseismology: historical and prehistorical records of earthquake ground effects for seismic hazard assessment. Geological Society, London, Special Publications, 316(1), 1-10.

Reitman, N. G., Bennett, S. E., Gold, R. D., Briggs, R. W., and DuRoss, C. B., 2015. High-resolution trench photomosaics from image-based modeling: Workflow and error analysis. Bulletin of the Seismological Society of America, 105(5), 2354-2366.

Rhodes, E. J., 2011. Optically stimulated luminescence dating of sediments over the past 200,000 years. Annual Review of Earth and Planetary Sciences, 39, 461-488.

Rhodes, E. J., 2015. Dating sediments using potassium feldspar single-grain IRSL: Initial methodological considerations. Quaternary International, 362, 14-22.

Rodríguez-Pascua, M. A., Pérez-López, R., Giner-Robles, J. L., Silva, P. G., Garduño-Monroy, V. H., and Reicherter, K., 2011. A comprehensive classification of Earthquake Archaeological Effects (EAE) in archaeoseismology: Application to ancient remains of Roman and Mesoamerican cultures.

Quaternary International, 242(1), 20-30.

Sadigh, K., Chang, C. Y., Egan, J. A., Makdisi, F., and Youngs, R. R., 1997. Attenuation relationships for shallow crustal earthquakes based on California strong motion data. Seismological Research Letters, 68(1), 180-189.

Salvi, S., Cinti, F. R., Colini, L., D'addezio, G., Doumaz, F., and Pettinelli, E., 2003. Investigation of the active Celano-L'Aquila fault system, Abruzzi (central Apennines, Italy) with combined groundpenetrating radar and palaeoseismic trenching. Geophysical Journal International, 155(3), 805-818. 
Serva, L., Blumetti, A.M., Guerrieri, L., and Michetti, A.M., 2002. The Apennine intermountain basins: the result of repeated strong earthquakes over a geological time interval. Atti Convegno "Evoluzione Geologica e Geodinamica dell'Appennino in memoria del Prof. Pialli". Boll. Soc. Geol. Ital. 1, 939-946.

Serva, L., Esposito, E., Guerrieri, L., Porfido, S., Vittori, E., and Comerci, V., 2007. Environmental effects from five historical earthquakes in southern Apennines (Italy) and macroseismic intensity assessment: Contribution to INQUA EEE Scale Project. Quaternary International, 173, 30-44.

Serva, L., Vittori, E., Comerci, V., Esposito, E., Guerrieri, L., Michetti, A. M., Mohammadioun, B., Mohammadioun, G. C., Porfido, S., and Tatevossian, R. E., 2016. Earthquake hazard and the Environmental Seismic Intensity (ESI) Scale. Pure and Applied Geophysics, 173(5), 1479-1515.

Špaček, P., Bábek, O., Štěpančíková, P., Švancara, J., Pazdírková, J., and Sedláček, J., 2015. The NysaMorava Zone: an active tectonic domain with Late Cenozoic sedimentary grabens in the Western Carpathians' foreland (NE Bohemian Massif). International Journal of Earth Sciences, 104(4), 963-990.

Štěpančíková, P., Hók, J., Nývlt, D., Dohnal, J., Sýkorová, I., and Stemberk, J., 2010. Active tectonics research using trenching technique on the south-eastern section of the Sudetic Marginal Fault (NE Bohemian Massif, central Europe). Tectonophysics, 485(1), 269-282.

Stiros, S., and Jones, R. E., 1996. Archaeoseismology. (Eds). Series: Fitch Laboratory occasional paper. Institute of Geology and Mineal Exploration: Athens.

Storchak, D.A., Di Giacomo, D., Bondár, I., Engdahl, E. R., Harris, J., Lee, W.H.K., Villaseñor, A., and Bormann, P., 2013. Public Release of the ISC-GEM Global Instrumental Earthquake Catalogue (19002009). Seism. Res. Lett., 84, 5, 810-815, doi: 10.1785/0220130034.

Stramondo, S., Tesauro, M., Briole, P., Sansosti, E., Salvi, S., Lanari, R., Anzidei, M., Baldi, P., Fornaro, G., Avallone, A., and Buongiorno, M. F., 1999. The September 26, 1997 Colfiorito, Italy, earthquakes: modeled coseismic surface displacement from SAR interferometry and GPS. Geophysical Research Letters, 26(7), 883-886.

Stucchi M., Rovida A., Gomez Capera A.A., Alexandre P., Camelbeeck T., Demircioglu M.B., Gasperini P., Kouskouna V., Musson R.M.W., Radulian M., Sesetyan K., Vilanova S., Baumont D., Bungum H., Fäh D., Lenhardt W., Makropoulos K., Martinez Solares J.M., Scotti O., Živcic M., Albini P., Batllo J., Papaioannou C., Tatevossian R., Locati M., Meletti C., Viganò D., and Giardini D., 2013. The SHARE European Earthquake Catalogue (SHEEC) 1000-1899. Journal of Seismology, 17, 2, pp.524-544. doi: http://doi.org/10.1007/s10950-012-9335-2.

Stucchi, M., Pinho, R., and Cocco, M., 2016. After the L'Aquila Trial. Seismological Research Letters, 87.3, 591-596.

Talebian, M., Biggs, J., Bolourchi, M., Copley, A., Ghassemi, A., Ghorashi, M., Hollingsworth, J., Jackson, J., Nissen, E., Oveisi, Parsons, B., Priestley, K., and Saiidi, A., 2006. The Dahuiyeh (Zarand) earthquake of 2005 February 22 in central Iran: reactivation of an intramountain reverse fault. Geophysical Journal International, 164(1), 137-148.

Tertulliani, A., Rossi, A., Cucci, L., and Vecchi, M., 2009. L'Aquila (central Italy) earthquakes: The predecessors of the April 6, 2009 event. Seismological Research Letters, 80(6), 1008-1013. 
Vittori, E., Labini, S. S., and Serva, L., 1991. Palaeoseismology: review of the state-of-the-art. Tectonophysics, 193(1), 9-32.

Vittori, E., Deiana, G., Esposito, E., Ferreli, L., Marchegiani, L., Mastrolorenzo, G., Michetti, A.M., Porfido, S., Serva, L., Simonelli, A.L., and Tonoli, E., 2000. Ground effects and surface faulting in the September-October 1997 Umbria-Marche (Central Italy ) seismic sequence. J. Geod. 29, 535-564.

Vittori, E., Di Manna, P., Blumetti, A. M., Comerci, V., Guerrieri, L., Esposito, E., Michetti, A. M., Porfido, S., Piccardi,L., Roberts, G. P., Berlusconi, A., Livio, F., Sileo, G., Wilkinson, M., McCaffrey, K. J. W., Phillips, R., J., and Cowie, P. A., 2011. Surface faulting of the 6 April 2009 Mw 6.3 L'Aquila earthquake in central Italy. Bulletin of the Seismological Society of America, 101(4), 1507-1530.

Wald, D. J., Heaton, T. H., and Hudnut, K. W., 1996. The slip history of the 1994 Northridge, California, earthquake determined from strong-motion, teleseismic, GPS, and leveling data. Bulletin of the Seismological Society of America, 86(1B), S49-S70.

Wallace, R. E., 1978. Geometry and rates of change of fault-generated range fronts, north-central Nevada. J. Res. US Geol. Surv, 6(5), 637-650.

Walters, R.J., Elliott, J.R., D'Agostino, N., England, P.C., Hunstad, I., Jackson, J.A., Parsons, B., Phillips, R.J., and Roberts, G., 2009. The 2009 L'Aquila earthquake (central Italy): A source mechanism and implications for seismic hazard. Geophysical Research Letters, 36(17).

Ward, S. N., and Valensise, G. R., 1989. Fault parameters and slip distribution of the 1915 Avezzano, Italy, earthquake derived from geodetic observations. Bulletin of the Seismological Society of America, 79(3), 690-710.

Working Group MS-AQ, 2010. Microzonazione sismica per la ricostruzione dell'area aquilana. Regione Abruzzo - Dipartimento della Protezione Civile, L'Aquila.

Xu, X., Wen, X., Yu, G., Chen, G., Klinger, Y., Hubbard, J., and Shaw, J., 2009. Coseismic reverse-and oblique-slip surface faulting generated by the $2008 \mathrm{Mw} 7.9$ Wenchuan earthquake, China. Geology, 37(6), 515-518.

Zhou, Y., Walker, R. T., Elliott, J. R., and Parsons, B., 2016. Mapping 3D fault geometry in earthquakes using high-resolution topography: Examples from the $2010 \mathrm{El}$ Mayor-Cucapah (Mexico) and 2013 Balochistan (Pakistan) earthquakes. Geophysical Research Letters, 43(7), 3134-3142.

Zielke, O., Klinger, Y., and Arrowsmith, J. R., 2015. Fault slip and earthquake recurrence along strikeslip faults-Contributions of high-resolution geomorphic data. Tectonophysics, 638, 43-62. 